\title{
DOKTORSKI STUDIJ INFORMACIJSKIH I KOMUNIKACIJSKIH ZNANOSTI NA SVEUČILIŠTU \\ U ZAGREBU - KONCEPTUALNE, STRUKTURNE I ORGANIZACIJSKE ODREDNICE
}

\author{
THE CONCEPTUAL, STRUCTURAL \\ AND ORGANISATIONAL FEATURES OF THE DOCTORAL \\ PROGRAMME IN INFORMATION AND COMMUNICATION \\ SCIENCES AT THE UNIVERSITY OF ZAGREB
}

\section{Jadranka Lasić-Lazić}

Odsjek za informacijske i komunikacijske znanosti

Filozofski Fakultet, Sveučilište u Zagrebu

jlazic@ffzg.hr

Sonja Špiranec

Odsjek za informacijske i komunikacijske znanosti

Filozofski Fakultet, Sveučilište u Zagrebu

sspiran@ffzg.hr

\author{
UDK / UDC [02:001.102:004:007]:378.046- \\ 021.68(497.5 Zagreb) \\ Pregledni rad / Review paper \\ Primljeno / Received: 12. 12. 2018. \\ Prihvaćeno / Accepted: 21. 9. 2020.
}

\section{Sažetak}

Cilj. Cilj je ovog rada prikazati konceptualne i strukturne odrednice Doktorskoga studija informacijskih i komunikacijskih znanosti na Sveučilištu u Zagrebu. Budući da je analiza doktorskog obrazovanja neodvojiva od promišljanja o znanstvenoistraživačkom identitetu i profiliranosti znanstvenog polja, rad će pokušati odgovoriti na pitanje o teorijskim postavkama i dvojbama koje su oblikovale konceptualna polazišta današnjega reformiranog Doktorskog studija informacijskih i komunikacijskih znanosti te na koji su način strategije i europske znanstvene politike definirale njegovu organizaciju

Vjesnik bibliotekara Hrvatske 63, 1-2(2020), 617-633 ISSN 0507-1925 
Pristup/metodologija. Polazeći od tvrdnje o nedostatku sustavnog uvida u literaturi o doktorskom obrazovanju u polju informacijskih znanosti, u radu se primjenom kvalitativnog pristupa analize literature koja problematizira teorijski profil polja informacijske i komunikacijske znanosti i ispitivanja smjernica doktorske izobrazbe u EU-u predočuju problemi i rješenja u restrukturiranju doktorskog obrazovanja u tom polju.

Rezultati. U radu se daje sustavni pregled konceptualnih i strukturnih odrednica Doktorskog studija informacijskih i komunikacijskih znanosti u Zagrebu i pritom argumentira da su reformska nastojanja neodvojiva od promišljanja o teorijskom opsegu i znanstvenom profilu polja, da se u strukturiranju programa moraju pronaći rješenja za intelektualnu i teorijsku disperziju u informacijskim znanostima te da EU-smjernice o doktorskom obrazovanju uvjetuju modularne pristupe u oblikovanju programa.

Originalnost/vrijednost. Rad popunjava relativnu prazninu u postojećoj literaturi o (re)modeliranju doktorskog obrazovanja u informacijskim znanostima i pritom polazi od teorijskih dvojbi u tom polju te EU-smjernica za strukturiranje doktorskih programa.

Ključne riječi: doktorski studij, informacijske i komunikacijske znanosti, načela doktorskog obrazovanja, program doktorskog studija, teorijski okviri

\section{Abstract}

Purpose. The aim of this paper is to present the conceptual and structural features of the doctoral programme in the field of information and communication sciences at the University of Zagreb. Since an analysis of a doctoral study programme is inseparable from deliberations over the identity and recognisability, and hence the status, of a given scientific field, the paper will attempt to provide an answer to the questions of theoretical groundwork and dilemmas that shaped the conceptual framework of the University's current, reformed doctoral programme in information and communication sciences and present how its organisation has been defined by the EU strategies and policies in science.

Methodology/approach. Addressing a lack of relevant resources that would enable the gaining of systematic insight into the history and development of doctoral programmes in information and communication sciences in Croatia, the paper presents the results of the qualitative analysis focusing on the literature outlining the theoretical profile of the field of information and communication sciences as well as on the EU guidelines on $\mathrm{PhD}$ programmes to present problems and solutions related to the restructuring of doctoral programmes in this field.

Findings. The paper provides a systematic overview of the conceptual and structural features of the doctoral programme in information and communication sciences at the University of Zagreb and presents arguments according to which all attempts at its reform are inseparable from deliberations over the field's theoretical scope, its recognisability and the related status. Also, it indicates as necessary that this doctoral programme 


\section{J. Lasić-Lazić, S. Špiranec:DOKTORSKI STUDIJ INFORMACIJSKIH I ...}

has to be (re)structured in such a way as to respond to the theoretical and intellectual dispersion characterising the field, and its modules be based on the EU guidelines on doctoral study programmes.

Originality/value. The paper presents a valuable response to a relative lack of resources and literature on the (re)modelling of doctoral programmes in the field of information sciences based on the analysis of theoretical dilemmas present in the field and the EU guidelines on structuring doctoral programmes.

Keywords: doctoral study, information and communication studies, doctoral programme, principles of doctoral education, theoretical frameworks

\section{Uvod}

Ideje o stvaranju Europskog prostora visokog obrazovanja, utemeljene kroz Bolonjsku deklaraciju, pokrenute su na najvišoj političkoj razini. Reforme koje su zahvatile cijeli europski prostor s idejom da se kroz mobilnost, otvorenost $\mathrm{i}$ kvalitetu doprinese razvoju društva usmjerile su se posebno na doktorske studije. Konkretna rasprava o strukturiranju doktorskih programa potaknula je ministarska konferencija u Berlinu ${ }^{1}$, nakon koje je organizirano niz konferencija i seminara na kojima se donose smjernice i načela modeliranja doktorskih studija u EU-u. Govori se o zajedničkim ciljevima koji će doprinijeti razvoju društva, a europski znanstveni prostor učiniti zajedničkim. Pritom su promjene koje zahvaćaju cjelokupno društvo utemeljene na informacijsko-komunikacijskoj tehnologiji, prijenosu informacija i znanja, brzoj komunikaciji istraživačkih rezultata putem interneta, a obrazovanje se postulira kao najjači segment stvaranja i posredovanja znanja koje mijenja cjelokupnu zajednicu. U takvom ozračju reformira se i doktorsko obrazovanje na hrvatskim sveučilištima. Unatoč tomu što su reformska promišljanja zahvatila doktorsko obrazovanje u svim područjima znanosti, polja poput informacijskih znanosti u procese promjena i restrukturiranja ulaze intenzivno i korjenito budući da je riječ o mladom i izrazito interdisciplinarnom polju. U takvim znanstvenim poljima reforme koje je trebalo provesti nisu bile samo strukturne ili organizacijske naravi nego su promišljanja nužno zahvatila i konceptualnu razinu i rasprave o intelektualnim ishodištima i teorijskom utemeljenju polja. ${ }^{2}$

\footnotetext{
1 Ostvarivanje Europskog prostora visokog obrazovanja: priopćenje s Konferencije ministara visokog obrazovanja, Berlin, 19. rujna 2003. [citirano:2018- 11-10]. Dostupno na: https://www. idi.hr/cerd/uploads/DOKUMENTI/Bolonja/Berlinska_deklaracija.pdf

2 Usp. Ferlindeš, J.; S. Špiranec. Teorijsko-filozofsko utemeljenje knjižnične i informacijske znanosti u filozofiji informacije. // Vjesnik bibliotekara Hrvatske 61, 1(2018), 37-56. DOI: https:// doi.org/10.30754/vbh.61.1.572
} 
Cilj je ovog rada prikazati razvoj te posebno konceptualne i strukturne odrednice današnjega Doktorskoga studija informacijskih i komunikacijskih znanosti koji se izvodi na Sveučilištu u Zagrebu. Budući da je analiza doktorskog obrazovanja neodvojiva od promišljanja o znanstvenoistraživačkom identitetu i profiliranosti znanstvenog polja, rad će pokušati odgovoriti na pitanje o teorijskim postavkama i dvojbama koje su oblikovale konceptualna polazišta današnjega reformiranog Doktorskog studija informacijskih i komunikacijskih znanosti te na koji su način strategije i europske znanstvene politike odredile njegovu organizaciju. Uz navedeno analizirat će se njegova unutarnja struktura koja je rezultat teorijskih promišljanja i opisanih strateških odrednica.

\section{Temelji Doktorskog studija informacijskih znanosti}

Započeti priču o doktorskom studiju u polju informacijskih znanosti, a danas i komunikacijskih znanosti, bez konteksta i temelja na kojima je nastao, ne bi bilo potpuno, a vizionarska ideja profesora Bože Težaka kao osnivača prvog poslijediplomskog studija u tome znanstvenom polju bila bi prešućena. Upravo ti temelji, koji su tada vizionarski postavljeni na Sveučilištu u Zagrebu, ujedno su polazište za današnji Doktorski studij informacijskih i komunikacijskih znanosti u Zagrebu.

I baš danas, kada se provode reforme i akreditacije svih doktorskih programa, od koristi je podsjetiti se ideje s kojom je na Sveučilište došao profesor Božo Težak i osnovao poslijediplomski studij koji je u vrijeme svoga osnutka bio ono što danas nude smjernice ministarske konferencije $\mathrm{u}$ Berlinu. ${ }^{3}$ Znao je profesor Težak da bez pristupa znanstvenim informacijama i bez informacijskih stručnjaka koji će znati obrađivati i pretraživati svjetsku znanstvenu baštinu nema razvoja vlastite znanosti, ni znanstvenog ni visokoškolskog sustava. Informacijsko-komunikacijska tehnologija u svojim počecima pokazuje da postaje pokretačka snaga razvoja i profesor Težak uvodi ju u studij. Danas tomu svjedoče konvencije i povelje međunarodnih organizacija, a većina nacionalnih smjernica navode ju kao razvojni potencijal koji mora biti svima dostupan te se pravo na pristup informacijama smatra jednim od temeljnih ljudskih prava u demokratskim društvima, a obrazovanje informacijskih stručnjaka kao potreba društva koje će kroz kompetentne stručnjake i protok informacija omogućiti razvoj zajednici i konkurentnost na tržištu. Kad je 1960-ih postignut konsenzus o opravdanosti osnivanja informacijske znanosti, nije postojala suglasnost o njezinu predmetu. U polje informacijskih znanosti kao discipline ulaze tada bibliotekarstvo, arhivistika, muzeologija, informatologija, koje do tada egzistiraju samo kao struke, a prvi obrazovni program ostvaruje tzv. Centar za studij bibliotekarstva, dokumentacije i informacionih znanosti (CSBDIZ). Studij je osnovan pri Prirodoslovno-matematičkom fakultetu Sveučilišta u Zagrebu, a 1964. postaje interfakultetski poslijediplomski studij Sveučilišta u Zagrebu.

3 Ostvarivanje Europskog prostora visokog obrazovanja. Nav. dj. 


\section{J. Lasić-Lazić, S. Špiranec:DOKTORSKI STUDIJ INFORMACIJSKIH I ...}

Osnutak tog poslijediplomskog studija obilježava početak znanstvenog utemeljenja informacijskih znanosti i integracije informacijskih disciplina u postojeće akademske i sveučilišne strukture u Hrvatskoj i tadašnjoj Jugoslaviji. Početnu jezgru znanstvenih disciplina interfakultetskog poslijediplomskog studija u sljedećem će desetljeću B. Težak proširiti znanstvenim disciplinama muzeologije, arhivistike, informatologije i komunikologije, konceptualno postavljajući i oblikujući temelje koje baštini današnji Doktorski studij informacijskih i komunikacijskih znanosti u Zagrebu. Povijesni obrazovni slijed današnjeg znanstvenog polja informacijskih i komunikacijskih znanosti, koje je vizionarski postavio i za koji je zaslužan profesor Božo Težak, neprijeporno je definirao današnji znanstveni status knjižničarstva i ostalih informacijskih disciplina koje bi bez tako postavljenih konceptualnih temelja potencijalno ostale na razini stručne djelatnosti bez matičnog znanstvenog polja ili bi put prema takvom statusu tekao znatno sporije.

Pitanja o teorijskim vidovima razvoja informacijskih znanosti predstavljala su polazište za teorijsko utemeljenje studija. Tu se, dakako, nije moglo raditi o jedinstvenoj teoriji zbog isprepletenosti disciplinama koje imaju koliko zajedničkih osnova, toliko i različitosti. Ključna ideja zajedništva vezala se uz definiranje informacije s jedne strane, određenje konteksta koji su definirale institucije koje su se bavile prikupljanjem, obradom, organizacijom, prezentacijom i diseminacijom podataka, informacija, zabilježenoga znanja posredovanog kroz medije. Vrijeme i društvene promjene te tehnološki razvoj, posebno razvoj informacijsko-komunikacijske tehnologije, određivali su polazišta pojedinih znanstvenika koji su znanost o informacijama htjeli podići na stupanj znanosti i egzaktnosti kakvu su imale prirodne znanosti, a s druge strane htjeli su konsolidirati područje koje je nastajalo iz starih tradicionalnih djelatnosti. Konsolidacija područja mogla se provesti kroz objedinjavanje područja i zajedničku jezgru studija

Informacijske znanosti, onako kako ih je vidio profesor Božo Težak, imale su za zadaću kroz obrazovni sustav iznjedriti znanstvenike i profesionalce koji će svojim istraživačkim i radnim konceptima pomoći razvoju znanosti i obrazovanja uopće usmjeravanjem na probleme organizacije i komunikacije informacija s kojim je bila suočena cjelokupna svjetska zajednica. Bez kvalitetnih, provjerenih i vrednovanih izvora informacija i znanja, koje je Težak vidio iskazane kroz svoju slavnu sintagmu e-t-ak-s-a kompleksa ${ }^{4}$, nije moguće razvijati i konkurirati u znanstvenom polju. Svjesnost da bez znanstvenih informacija i informacijskih stručnjaka nema kvalitetnih istraživanja ni u jednom znanstvenom području $\mathrm{u}^{5}$, Božo Težak nastojao je povezati nastavu i istraživanje te na znanstvenim temeljima ustrojiti informacijsko-komunikacijske sustave, što je na operativnoj razini rezul-

\footnotetext{
4 E-t-ak-s-a kompleks odnosi se na teoriju i praksu emisije, transmisije, selekcije i apsorpcije informacija.

5 Težak, B. Informaciono-dokumentaciono-komunikacioni (INDOK) sistem. // Informatologia Yugoslavica 1, 1/4(1969), 1-2.
} 
tiralo osnivanjem Referalnog centra Sveučilišta u Zagrebu 1967. godine. Koncept Referalnog centra koji je razradio Težak ${ }^{6}$ pokazni je primjer uvažavanja ne samo načela interdisciplinarnosti (kojim se Težak prethodno vodio u osnivanju Poslijediplomskog studija knjižničarstva, dokumentacije i informacijskih znanosti) već i multidisciplinarnosti i transdisciplinarnosti. Time je profesor Težak vizionarski predvidio razvojnu putanju doktorskog obrazovanja koja je sadržana u današnjim europskim političkim smjernicama i dokumentima, ali i suvremena tumačenja informacijskih znanosti koja se teorijski istovremeno naslanjaju na znanstvene tradicije tehničkih, društvenih i humanističkih disciplina. Zahvaljujući znanstvenoj misli profesora Težaka ta je razvojna putanja od samih početaka ugrađena u temelje poslijediplomskog obrazovanja u informacijskom području, a danas i na Doktorskom studiju informacijskih i komunikacijskih znanosti na Sveučilištu u Zagrebu.

\section{Reforma studija informacijskih i komunikacijskih znanosti kao trećeg ciklusa obrazovanja}

Doktorski studij informacijskih znanosti kreće 2005. godine kao treći ciklus obrazovanja prema bolonjskom sustavu. U samim početcima studij još nije jasno usmjeren prema istraživanju jer studenti prvo slušaju i polažu ispite. Doktorat jest istraživački rad, ali on je završni rezultat studija. Studij je bio postavljen na obaveznim i izbornim predmetima koje kandidati slušaju i biraju prema svom interesu, dok se doktorat prijavljuje na trećoj godini studija kada su položeni svi propisani ispiti i objavljen jedan rad u suradnji s mentorom. Očito je takva struktura studija bila u raskoraku s idejama i okvirima iskazanima u relevantnim EU-dokumentima o doktorskoj izobrazbi, pa je vrlo brzo nakon uspostave studija postalo jasno da je studij potrebno reformirati, a prva se značajnija formalna promjena dogodila 2010. nakon promjene u strukturi znanstvenog polja, čiji je naziv promijenjen u informacijske i komunikacijske znanosti i umjesto prijašnjih osam grana obuhvatio 11 znanstvenih grana. ${ }^{7}$ Ta se promjena odrazila na doktorski studij koji se otvara prema novim granama, dok se istovremeno kreće u promišljanje o promjenama na trima razinama: koncepcijskoj i sadržajnoj, strukturnoj i organizacijskoj, što je rezultiralo novim studijskim programom koji je 2017. godine prošao postupak akreditacije. U nastavku ćemo prikazati polazišta modeliranja studija na konceptualnoj, strukturnoj i organizacijskoj razini.

${ }_{6}$ Težak, B. Referalni centar Sveučilišta u Zagrebu: (pregledni, bitni i osobiti podaci o Referalnom centru). // Informatologia 40, 1(2007), 14-19. Dostupno i na: https://hrcak.srce.hr/index. php?show=clanak\&id_clanak_jezik=20458 [citirano: 2020-08-20].

7 Pravilnik o znanstvenim i umjetničkim područjima, poljima i granama. // Narodne novine 118(2009), 82(2012), 32(2013), 34(2016). Dostupno i na: http://www.propisi.hr/print. php?id=9662 [citirano: $2018-11-10]$. 


\section{J. Lasić-Lazić, S. Špiranec:DOKTORSKI STUDIJ INFORMACIJSKIH I ...}

\subsection{Konceptualne smjernice modeliranja studija}

U postavljanju konceptualnih temelja doktorskoga studija moralo se krenuti od promišljanja o informacijskim znanostima kao polju i znanstvenoj disciplini te od relacija tog polja u odnosu na ostala akademska i znanstvena područja. Polazišta za takva promišljanja pružao je bogat korpus literature u kojoj prevladavaju tvrdnje o nepostojanju jedinstvene i općeprihvaćene definicije znanstvenog polja informacijske znanosti ${ }^{8}$ ili disperziji njegovih intelektualnih polazišta, pri čemu se znanstveni status nerijetko osporava ili se pak kritizira njegova praktična usredotočenost. ${ }^{9} \mathrm{~S}$ druge strane globalno nisu provedene obuhvatne analize o doktorskoj izobrazbi u polju informacijskih znanosti ${ }^{10}$ koje bi mogle poslužiti kao okvir redefiniranja doktorskog studija.

Dobar uvid u način promišljanja o informacijskim znanostima dala je studija Knowledge Map of Information Science koja je provedena s ciljem istraživanja teorije informacijske znanosti i definiranja pojmova informacijskih znanosti, a u kojoj je sudjelovalo 57 vodećih znanstvenika iz 16 zemlja. Istraživanje i reakcije na to istraživanje pokazala su velike razlike u razumijevanju informacije i informacijskih znanosti ${ }^{11}$ te različitost $u$ pristupu polju informacijskih znanosti, pri čemu je izdvojeno nekoliko modela: a) model visokih tehnologija (usmjeren na računalne tehnologije), b) tehnološki model (usmjeren na tehnologiju bilo koje vrste), c) model kulture/društva (usmjeren na društvene aspekte), d) model sfere ljudi (usmjeren na čovjeka), e) model živog svijeta (zahvaća svijet ljudi i ostalih živih bića) ${ }^{12}$ te model živog i fizičkog svijeta (usmjeren na sve biološke organizme i fizički svijet). Ta i druge slične studije ${ }^{13}$ pokazale su da ne postoji jedinstve-

\footnotetext{
8 Robinson, L.; M. Karamuftuoglu. The nature of information science: changing models. // Information Research: An International Electronic Journal 15,4(2010). [citirano: 2018- 11-10]. Dostupno na: http://www.informationr.net/ir/15-4/colis717.html

9 Ferlindeš, J.; S. Špiranec. Nav. dj.

10 Sugimoto, C. R.; T. G. Russell; S. Grant. Library and information science doctoral education: the landscape from 1930-2007. // Journal of Education for Library and Information Science 50, 3(2009), str. 190. Dostupno i na: https://www.jstor.org/stable/40732578 [citirano: 2018- 11-10].

11 Usp. Zins, C. Zins, C. Conceptions of information sciences. // Journal of the American Society for Information Science and Technology 58, 3(2007), 335-350. DOI: https://doi.org/10.1002/ asi.20507; Zins, C. Conceptual approaches to defining data, information, and knowledge. // Journal of the American Society for Information Science and Technology 58, 4(2007), 479-493. DOI: https://doi.org/10.1002/asi.20508; Zins, C. Knowledge map of information science. // Journal of the American Society for Information Science and Technology 58, 4(2007), 526-535. DOI: https://doi.org/10.1002/asi.20505; Zins, C. Classification schemes of information science: twenty-eight scholars map the field. // Journal of the American Society for Information Science and Technology 58, 5(2007), 645-672. DOI: https://doi.org/10.1002/asi.20506

12 Model d) i e) djelomično se preklapaju.

13 Bawden, D. Smoother pebbles and the shoulders of giants: the developing foundations of information science. // Journal of Information Science 34, 4(2008), 415-426. DOI: http://dx.doi. org/10.1177/0165551508089717
} 
na koncepcija informacijske/ih znanosti. Informacijske znanosti kao polje slijede različite pristupe (npr. objektivni nasuprot kognitivnim pristupima) i različite tradicije (npr. knjižnična, dokumentalistička, računalna tradicija), što implicira i različite domene znanja. ${ }^{14} \mathrm{Uz}$ navedeno definiranje konceptualnog profila Doktorskog studija informacijskih i komunikacijskih znanosti u Hrvatskoj dodatno je usložilo proširenje znanstvenog polja komunikacijskom komponentom, iako je takav integrirajući pristup ranije prepoznat $\mathrm{u}$ literaturi ${ }^{15}$ te implementiran u usporedivim doktorskim studijima u svijetu ${ }^{16}$. No bez obzira na disciplinarnu identifikaciju i profiliranost pojedinog doktorskog programa (npr. knjižnična i informacijska znanost, dokumentalistika, informacijski sustavi, komunikacijske znanosti), glavna je odlika svih usporedivih programa, pa i Doktorskog studija informacijskih i komunikacijskih znanosti u Zagrebu, izrazita interdisciplinarnost i multidisciplinarnost koje izviru iz univerzalne i modificirajuće prirode pojma informacije i njegovoj pripadnosti različitim područjima. Tomu treba dodati i promijenjenu i danas središnju ulogu informacija u društvu, što je dodatno potaknulo potrebu razvoja novih pristupa doktorskom obrazovanju kako bi se zadovoljila očekivanja i zahtjevi društva i znanosti u odnosu na univerzalnu središnju ulogu informacija. ${ }^{17}$ Polazeći od takve uloge i sve veće složenosti informacijskih procesa i interakcija, interdisciplinarnost, koja omogućuje združivanje različitih perspektiva u rješavanju složenih problema, postaje glavnim obilježjem informacijskih znanosti. No takav pristup ujedno donosi značajne izazove, osobito u izgradnji zajedničkih polazišta, rječnika koji se koristi u opisivanju fenomena ili referentnih točaka polja. Stoga se u konceptualizaciji Doktorskog studija informacijskih znanosti u Zagrebu, slično kao i u drugim studijima informacijskih znanosti u svijetu ${ }^{18}$, odustalo od inzistiranja na kruto i čvrsto definiranoj teorijskoj jezgri studija, već je studente željelo izložiti emergentnim i širokim interdisciplinarnim perspektivama kroz kombinaciju različitih modula i istraživačkih tema. Takav pristup nikako nije podrazumijevao teorijsku neutemeljenost ili potpunu teorijsku disperziju, već je

14 Robinson, L.. ; M. Karamuftuoglu. Nav. dj.

15 Borgman, C. L.; R. E. Rice. The convergence of information science and communication: a bibliometric analysis. // Journal of the American Society for Information Science 43, 6(1992), 397411. DOI: https://doi.org/10.1002/(SICI)1097-4571(199207)43:6<397::AID-ASI1>3.0.CO;2-M

16 Usp. Rutgers., Ph.D. in Communication, Information \& Media. [citirano: 2018- 11-10]. Dostupno na: https://comminfo.rutgers.edu/academics/graduate/phd-program-communication-information-and-media; Kent State University. Ph.D. in Information and Communication. [citirano: 2018- 11-10]. Dostupno na: https://www.kent.edu/iSchool/phd-communication-information-2; UCD School of Information and Communication Studies Doctoral Programme. [citirano: 201811-10]. Dostupno na: https:/www.ucd.ie/ics/study/phdresearchprogrammes/

17 Druin, A.; P. T. Jaeger; J. Golbeck; K. R. Fleischmann; J. Lin; Y. Qu; P. Wang; B. Xie. The Maryland modular method: an approach to doctoral education in information studies. // Journal of Education for Library and Information Science 50, 4(2009), str. 293. Dostupno i na: https://www. jstor.org/stable/40732590?seq=1\#metadata_info_tab_contents [citirano: 2018-11-10].

18 Isto, str. 299. 


\section{J. Lasić-Lazić, S. Špiranec:DOKTORSKI STUDIJ INFORMACIJSKIH I ...}

ponuđen teorijski modul koncepcijom obuhvatio tri pravca teorijskih promišljanja: prvi čini utjecaj znanstvenika koji dolaze iz prirodno-tehničkog područja te teorijska polazišta traže u egzaktnosti prirodnih znanosti, a pritom žele poduprijeti konsolidaciju područja koje je izrazito smješteno u društveno-humanistički kontekst; drugi pravac teorijskih polazišta iščitavamo iz sociološkog, lingvističkog i filozofskog miljea; te treći koji je okrenut medijima i komunikaciji.

\subsection{Modeliranje studija - strukturne smjernice}

Strukturni okvir reforme studija informacijskih i komunikacijskih znanosti u Zagrebu pružila su brojna priopćenja, dokumenti, a kasnije i smjernice koje su objavljivane od 1990-ih u kontekstu stvaranja Europskog istraživačkog prostora (tzv. bolonjski proces). U fokus pažnje doktorski su studiji došli na ministarskoj konferenciji u Berlinu 2003. godine, kada se naglašava njihova ključna uloga u procesu kohezije Europskog istraživačkog prostora, a doktorski se programi identificiraju kao studiji trećeg ciklusa koji prenose istraživačka znanja i vještine te promiču interdisciplinarnost. Priopćenje ${ }^{19}$ objavljeno nakon ministarske konferencije u Berlinu potaknulo je brojne druge dokumente, aktivnosti i studije u kojima se promišljalo o budućnosti doktorskog obrazovanja u Europi, a ključni dokument čine tzv. Salzburška načela koja su nastala s ciljem usmjeravanja i objedinjavanja smjerova reforme doktorske izobrazbe. ${ }^{20}$ Načela prije svega ističu posebnost doktorske izobrazbe u odnosu na prvi i drugi ciklus visokog obrazovanja budući da se ono temelji na provođenju istraživanja koje je individualno i jedinstveno te institucije koje vode doktorsko obrazovanju moraju graditi i njegovati istraživački mentalni sklop. Pet godina nakon objave Salzburških načela Vijeće za doktorsku izobrazbu Europskog udruženja institucija visokog obrazovanja (EUA) objavilo je dokument Salzburg II, kao nadogradnju izvornih Salzburških načela, koji osnažuje valjanost Načela i konkretizira njihov sadržaj. ${ }^{21}$

Za Doktorski studij informacijskih i komunikacijskih znanosti u Zagrebu Salzburška su načela signalizirala drugačiju koncepciju studija, ponajprije u odnosu na razumijevanje i strukturiranje nastavnog procesa, a potom i u odnosu na ulogu doktoranda. U nastavku analiziramo one kriterije iz Načela koji su uporabljeni kao polazišne točke restrukturiranja Doktorskog studija informacijskih i komunikacijskih znanosti (IKZ) u Zagrebu. Načela u prvom redu ističu individualizirani

19 Ostvarivanje Europskog prostora visokog obrazovanja. Nav. dj.

20 Bologna Seminar on "Doctoral Programmes for the European Knowledge Society", (Salzburg, 3-5 February, 2005). Conclusions and recommendations. [citirano: 2018- 11-10].

Dostupno na: https://eua.eu/downloads/publications/salzburg\%20recommendations\%202005.pdf

${ }^{21}$ Salzburg II preporuke: postignuća europskih sveučilišta u razdoblju nakon 2005. u ostvarivanju Salzburških načela. Zagreb: Sveučilište u Zagrebu, 2011. [citirano: 2018- 11-10]. Dostupno na: http://www.unizg.hr/fileadmin/rektorat/Istrazivanja/Poslijediplomski/Ured_za_doktorske studije_i_programe/Publikacije/Salzburg_II_preporuke.pdf 
pristup doktorandu i istraživački fokus kroz cijeli studij koji je usmjeren na oblikovanje izvornog, konkretnog istraživačkog projekta:

„doktorska izobrazba u visokom je stupnju individualna i po definiciji izvorna. Put napredovanja svakog pojedinca je jedinstven, i u pogledu njegova istraživačkog projekta, i u pogledu njegova profesionalnog razvoja." ${ }^{22}$

Navedena je smjernica podrazumijevala utemeljenje nastave na oblicima aktivnosti različitim od predavanja i mogućnost kombiniranja takvih aktivnosti prema individualnim potrebama studenata. Broj je obaveznih kolegija sukladno smjernicama smanjen, uz povećanje bodova za različite druge istraživačke aktivnosti (individualne i grupne). Poštujući jedinstven put pojedinca u njegovu sazrijevanju u istraživača i znanstvenika, studij je izrazito razgranao načine stjecanja ECTS-bodova, pri čemu klasičnih ispita gotovo nema. Bodove student prikuplja kroz individualni rad s nastavnicima studija, a kasnije i mentorom na istraživačkim temama i projektima, postavljanje i reviziju vlastite istraživačke strategije, sudjelovanje na konferencijama i radionicama kojima doktorand razvija i osnažuje istraživačke i generičke kompetencije, držanje nastave i predavanja, boravke na stranim sveučilištima, grupnim radom i rješavanjem projektnih zadataka u okviru ljetnih škola i sl. Drugim riječima, studij je koncipiran tako da doktorand aktivno osmišljava i zajedno s mentorom izrađuje strategiju vlastitog razvoja istraživačke karijere, a instrumenti vrednovanja rada doktoranda u potpunosti se razlikuju od pristupa na preddiplomskom ili diplomskom studiju te su u cijelosti utemeljeni na istraživačkoj komponenti studija.

Dokument Salzburg II posebno ističe transparentne procedure upisa na studij, kao i potrebu osiguravanja kvalitetnog sustava mentorstva. Temeljem tog skupa načela na Doktorskom su studiju IKZ-a u Zagrebu detaljno razrađeni kriteriji upisa pristupnika, pri čemu je stavljen naglasak na inicijalni istraživački interes kandidata, njegovo planirano područje istraživanja i njegovu percepciju razvoja znanstvene karijere. Struktura studenata koji upisuju Doktorski studij IKZ-a u Zagrebu pokazuje da su njihova teorijska polazišta diferencirana na prirodno/tehničko i društveno/humanističko područje. Tako široko postavljenu bazu trebalo je integrirati u istraživanje, ali i otvoriti puteve za dodatno profiliranje njihove karijere, ne samo unutar istraživanja i institucija koje su financijski pokrivale njihov rad već je kroz interdisciplinarnost trebalo sagledati i odgovoriti znanstvenom metodologijom na istraživačka pitanja i probleme. Jasno je bilo da tako široko postavljeno područje istraživanja bez jasno definiranog predmeta istraživanja treba i dobro koncipiran mentorski sustav i veliki izbor mentora. Kvalitetan sustav mentoriranja stoga čini okosnicu studija, a budući da se studij izvodi u suradnji s fakultetima zagrebačkog sveučilišta (npr. Hrvatski studiji, Političke znanosti) i institucijama

22 Isto, str. 3. 


\section{J. Lasić-Lazić, S. Špiranec:DOKTORSKI STUDIJ INFORMACIJSKIH I ...}

koje zapošljavaju ili financiraju doktorande (knjižnice, arhivi, muzeji) te vanjskim stručnjacima i znanstvenicima studij je osigurao široku bazu mentora. Znanstvenoistraživački kapital studija IK-znanosti ne počiva samo na mentorima koji pokrivaju područje IKZ-a već uključuje i mentore sa svih 19 doktorskih studija Filozofskog fakulteta koji čine istraživačku i mentorsku platformu Doktorskog studija IKZ-a. Opisana široka mentorska baza ocrtava i ujedno ostvaruje već spomenutu interdisciplinarnost kao jedno od ključnih polazišta doktorskog obrazovanja definiranog u Salzburškim načelima.

Znanstveni kapital Doktorskog studija IKZ-a postao je tako mjesto razvoja znanstvenog podmlatka te razvoja i rasta mentorskih kapaciteta koji je okupljen oko Doktorskog studija i čini vrlo jaku znanstvenu i prepoznatljivu institucionalnu jezgru iz koje su izašli mnogi doktori znanosti, danas zaposleni na sveučilištima u cijeloj regiji.

Doktorskim studentima na samom početku studija dodijeljen je mentor savjetnik, uz pomoć kojeg student izrađuje vlastitu strategiju istraživanja. U kasnijoj fazi studija imenuje se i mentor prema temi istraživanja. Pravila ponašanja mentora i kandidata utvrđena su pravilnikom.

Na strukturiranje studija IKZ-a posebno je utjecalo 8. načelo Salzburških načela koje ističe razvoj prenosivih vještina; tom skupu vještina u reformiranom programu posvećen je zaseban modul koji će pobliže biti opisan u sljedećem poglavlju.

\section{Reformirani Doktorski studij informacijske i komunikacijske zna- nosti u Zagrebu: sadržajna težišta i organizacijske odrednice}

Usklađivanje Doktorskog studija IKZ-a sa Salzburškim načelima trebalo je krenuti od definiranja znanstvenoistraživačkog smjera i profila studija prema znanstvenoj strategiji institucije, što se pokazalo izazovom jer u tom trenutku znanstvenoistraživačka strategija Filozofskog fakulteta ${ }^{23}$ još nije postojala. U strateškom utemeljenju studija stoga se krenulo od pojedinih strateških dokumenata Sveučilišta u Zagrebu, načela doktorske izobrazbe u EU-u ${ }^{24}$, samoanalize postojećeg stanja (SWOT-analiza) i uočavanju svjetskih tokova u području informacijskih i komunikacijskih znanosti te društvenih znanosti. ${ }^{25}$

23 Filozofski fakultet Sveučilišta u Zagrebu usuglasio je Strateški plan istraživanja 2018. godine.

24 Uz Salzburška načela u koncipiranju se pošlo od dokumenata poput Kottmann, A.; E. Weyer. Exploration of the implementation of the principles for innovative doctoral training in Europe: final report. Brussels: European Commission, 2013. [citirano: 2018- 11-10]. Dostupno na: http:// doc.utwente.nl/88802/.

25 Strategija doktorskog studija Informacijske i komunikacijske znanosti: 2015. - 2020. // Sveučilište u Zagrebu. Filozofski fakultet. Odsjek za informacijske i komunikacijske znanosti. [citirano: 2018- 11-10]. Dostupno na: https://inf.ffzg.unizg.hr/index.php/hr/studij/poslijediplomski-doktorski-studij/plan-i-program 
Studij je svoj jedinstveni znanstvenoistraživački profil utemeljio na nekolicini strateških područja u kojima nastavnici studija istražuju kompetitivne teme u međunarodnim istraživačkim timovima, što doktorskim studentima osigurava potencijal za međunarodno umrežavanje. Jedinstven znanstveni profil studij ostvaruje u sljedećim područjima: 1) informacijske prakse i znanje u digitalnom okruženju, 2) digitalni dokumenti i zapisi kao vjerodostojni izvori, 3) digitalna lingvistika i istraživanje jezika i govora, 4) društvena relevantnost baštine u 21. stoljeću, 5) izazovi kodifikacije, razmjene i stvaranja znanja, 6) konceptualne, metodološke i društvene odrednice suvremene masovne komunikacije.

Sadržajno fokusiranje studija u znanstvenom polju kao što su informacijske i komunikacijske znanosti pokazalo se pravim izazovom, ne samo zbog interdisciplinarnosti već i zbog različitih tumačenja o predmetu polja i pripadnosti tog predmeta drugim znanstvenim poljima i područjima, a izazov sadržajnog fokusiranja dodatno je došao do izražaja nakon proširenja polja na komunikacijsku komponentu. Prvi korak svakako je bio odmak od institucijskog utemeljenja istraživačkog profila studija (npr. fokus na knjižnice, arhive, muzeje, škole itd.) koje je bilo glavna odrednica prethodnih programa, prema informacijama, medijima i povezanim informacijskim i komunikacijskim praksama. ${ }^{26}$ Sadržaji studija stoga su usmjereni prema istraživanju interakcija među ljudima, podataka/ informacija/medijskih sadržaja, digitalnih tehnologija i društva te na konceptualizaciju i razvoj suvremenih informacijskih i medijskih sustava koji podupiru takve interakcije. Takva istraživanja svojim rezultatima doprinose razvoju kapaciteta pojedinaca, organizacija (baštinski i javni sektor, gospodarstvo) i društva za učinkovito i smisleno upravljanje, uporabu i priopćavanje podataka, informacija i medijskih sadržaja.

Utemeljenje studija na EU-načelima doktorske izobrazbe, kao što su istraživačko osposobljavanje, interdisciplinarnost i prenosive vještine podrazumijevalo je zaokret u strukturiranju programa koji više nije oblikovan linearno, već modularno. Studij je strukturiran u 4 obavezna modula unutar kojih postoje obvezni i izborni elementi: 1 . teorijski modul; 2 . metodološki modul; 3 . istraživačke teme; 4. transferne/generičke vještine. U prvoj godini kandidati vođeni mentorskim savjetnikom pripremaju teorijske i metodološke predmete koji su važni za ulazak u znanstvenoistraživački rad. U drugoj godini doktorandi biraju samostalno ili uz pomoć mentora savjetnika istraživačke teme. Tijekom semestara uz nastavne aktivnosti kroz teorijski i metodološki modul bodove prikupljaju različitim znanstvenoistraživačkim aktivnostima (istraživačkim seminarima, objavljivanje znanstvenog rada, izrada osobne strategije i plana istraživačke karijere, rad s mentorom na istraživačkim temama, sudjelovanjem na konferencijama, sudjelovanjem

26 Larivière, V.; C. R. Sugimoto; B. Cronin. A bibliometric chronicling of library and information science's first hundred years. // Journal of the American Society for Information Science and Technology 63, 5(2012), 1013. DOI: https://doi.org/10.1002/asi.22645 


\section{J. Lasić-Lazić, S. Špiranec:DOKTORSKI STUDIJ INFORMACIJSKIH I ...}

u nastavi diplomskih studija, radionicama za unaprjeđenje generičkih i prenosivih kompetencija, boravkom na stranim sveučilištima itd.).

Teorijski modul bilo je najteže strukturirati zbog već spomenute teorijske disperzije u informacijskim i komunikacijskim znanostima. Taj modul čine predmeti teorije područja i polja istraživanja te izborni dio teorije koja pokriva temu istraživanja kandidata; neki od predmeta koji se kandidatima nude su Epistemologija društvenih znanosti, Filozofija znanosti, Teorija informacijskih znanosti, Teorije medija i medijski sadržaj, Teorija masovnog komuniciranja, Baština i razvoj, Teorija informacija i komunikacija.

Metodološki modul čine predmeti iz opće metodologije istraživanja, znanstvenih metoda, istraživačkih postupaka. Zbog zahtjeva za jačim fokusiranjem na istraživačku komponentu novi program zahtijevao je više kolegija i radionica posvećenih metodologiji i metodama istraživanja. Pritom se nude opći metodološki premeti (Metodologija društvenih znanosti, Metodologija istraživanja u informacijskim znanostima), uz ravnomjernu zastupljenost predmeta i radionica posvećenih kvalitativnim, kvantitativnim i mješovitim metodološkim pristupima, što je neophodno u tako širokom i interdisciplinarno postavljenom polju istraživanja.

Modul istraživačkih seminara čine različite istraživačke teme koje su u suglasju sa Strategijom znanstvenih istraživanja doktorskog studija, a koje student bira prema temi doktorske disertacije.

Modul transfernih/prenosivih vještina organiziran je u vidu radionica koje omogućuju razvijanje istraživačkih, ali i komunikacijskih, upravljačkih i poslovnih vještina koje bi trebale pomoći doktorandima pri iskorištavanju vlastitog znanstvenog potencijala, tijekom, ali i nakon doktorskog studija te primjenu tih vještina u svijetu rada. Modul je strukturiran u 2 dijela: akademsku i poslovno-organizacijsku cjelinu. Poslovno-organizacijski blok sadržajima osigurava transfer i aplikaciju vještina stečenih na doktorskom studiju za kreativno rješavanje problema i izvan užeg akademskog sektora jer obuhvaća teme poput upravljanja projektima, poduzetništva (npr. privlačenje financiranja, pokretanje startupova, strateški alati, upravljanje ljudskim potencijalima, timski rad, prezentacijske i komunikacijske vještine itd.). ${ }^{27}$

Doktorski studij IKZ-a posebnu pažnju posvećuje i sustavno potiče znanstvenu aktivnost doktoranda, što je predviđeno i programom studija. Pritom studij

27 Primjeri radionica akademskih vještina: 1. Recenzije i recenzentski postupak u znanosti; 2. Znanstvena čestitost; 3 . Pretraživanje znanstvenih informacija (tradicionalnim elementima i mehanizmima znanstvene komunikacije i alternativnim modelima praćenja znanstvene produkcije (npr. Research Gate); 4. Pisanje znanstvenih radova; 5. Popularizacija znanosti (osposobljavanje za izgradnju online identiteta te strateško umrežavanje u svrhu razvijanja, održavanja i korištenja istraživačkih mreža, primjenom metoda i alata multimedijske prezentacije i sl.).

Sadržaj radionica poslovnoorganizacijskih vještina: 1 . Upravljanje projektima; 2. Poduzetništvo u akademskom okruženju; 3. Prezentacijske i komunikacijske vještine, govorništvo; 4. Profesionalni razvoj (elementi upravljanja vremenom, alati za organizaciju u upravljanju informacijama). 
sufinancira sudjelovanje na međunarodnim znanstvenim konferencijama te omogućava znanstveno usavršavanje u vidu kraćih ili duljih boravaka na uglednim inozemnim znanstvenim institucijama i radionicama. U tom kontekstu posebno treba istaknuti dva međunarodna skupa i ljetnu školu koje doktorski studij suorganizira: European Conference on Information Literacy (ECIL) ${ }^{28}$, The Future of Information Sciences (InFuture) ${ }^{29}$ i Ljetnu školu Informacijska tehnologija i mediji (ITMed) ${ }^{30}$. Radovi se s tih skupova objavljuju i važna su platforma za diseminaciju rezultata znanstvenog istraživanja.

Posebno velik broj doktoranada sudjeluje u ljetnim školama Odsjeka za informacijske i komunikacijske znanosti Filozofskog fakulteta Sveučilišta u Zagrebu organiziranima u Zadru, čiji je primarni cilj jačati znanstvene i istraživačke kapacitete doktoranda i ponuditi platformu na kojoj doktorandi, nastavnici, domaći i međunarodni stručnjaci, alumniji doktorskog studija, ali i suradnici i gosti razmjenjuju ideje i iskustva u savladavanju izazova i mogućnosti na putu prema doktorskoj tituli i istraživačkoj karijeri. Ekspertni raspon sudionika doktorskog kolokvija predočuje i temeljnu odrednicu cijelog Doktorskog studija IKZ-a u Zagrebu, a riječ je o konceptualnoj integraciji informacijskog, komunikacijskog i medijskog područja kroz sjedinjenje tehnologijom i novim kanalima komunikacije u znanosti. Stoga su i Ljetna škola, pa i doktorski kolokvij, tematski fokusirani na nove informacijske i komunikacijske platforme te konvergenciju informacijskih i medijskih prostora koji pred informacijske i komunikacijske stručnjake i znanstvenike postavljaju izazove koji se nalaze u istom semantičkom registru te njihovo rješavanje zahtijeva zajednički pristup, otvarajući pritom snažne istraživačke prostore prema kojima se mladi istraživači mogu usmjeravati u svojim doktorskim temama.

Doktorska ljetna škola, kao i doktorski kolokviji koji se organiziraju tijekom godine, a na kojima doktorandi izlažu svoje istraživačke teme i projekte, pokazali su se inspirativnima za sam istraživački proces kroz koji prolaze doktorandi, budući da takvi susreti pomažu u modificiranju ili preoblikovanju tematskih i

28 ECIL je međunarodna konferencija posvećena konceptu informacijske pismenosti koju su 2013. godine pokrenuli Odsjek za upravljanje informacijama Sveučilišta Hacettepe iz Ankare i Odsjek za informacijske i komunikacijske znanosti Filozofskog fakulteta Sveučilišta u Zagrebu. Konferencija redovito okuplja 300 do 400 sudionika iz cijeloga svijeta, a održava se u različitim europskim gradovima. Više informacija dostupno na: http://ilconf.org/

29 INFuture je međunarodna konferencija koju organizira Odsjek za informacijske i komunikacijske znanosti Filozofskog fakulteta Sveučilišta u Zagrebu i koja je namijenjena znanstvenicima i stručnjacima u polju informacijskih i komunikacijskih znanosti. Više informacija o konferenciji: https://infoz.ffzg.hr/INFuture/

30 Ljetnu školu ITMed organiziraju Sveučilište u Zadru (Odjel za turizam i komunikacijske znanosti) i Sveučilište u Zagrebu (Odsjek za informacijske i komunikacijske znanosti Filozofskoga fakulteta, Fakultet Hrvatski studiji, Fakultet političkih znanosti), a u okviru Ljetne škole održava se doktorski kolokvij. Više informacija o ljetnoj školi: http://conference.unizd.hr/blog/2019/04/24/ ljetna-skola-informacijska-tehnologija-i-mediji-2019/ 


\section{J. Lasić-Lazić, S. Špiranec:DOKTORSKI STUDIJ INFORMACIJSKIH I ...}

interesnih težišta disertacije, a pokazali su se inspirativnima i za stručnjake iz prakse koji se kroz kolokvij i izlaganja tema doktoranada upoznaju s načinom promišljanja i analizama mladih znanstvenika. Na taj se način otvara mogućnost umrežavanja i postavlja početna točka za izgradnju budućih istraživačkih mreža u kojima se prožimaju znanstvene spoznaje i njihova potencijalna praktična primjena.

\section{Zaključak}

Reforma doktorskog obrazovanja složen je proces koji je u posljednjem desetljeću zahvatio doktorske programe u EU-u u svim područjima znanosti. U područjima znanosti u kojima su načela doktorskog obrazovanja podudarna sa samom naravi znanstvenog polja, kao što je načelo interdisciplinarnosti odlika informacijskih i komunikacijskih znanosti, očekivalo bi se da će proces provođenja reforme biti jednostavan i manje izazovan. No pokazalo se da se izrazito interdisciplinarna polja, kao što su informacijsko i komunikacijsko, suočavaju s poteškoćama u definiranju opsega i dosega osnovnog predmeta istraživanja ili teorijske omeđenosti svoga intelektualnog prostora, što svakako predstavlja izazov u oblikovanju obrazovnih programa, posebno na doktorskoj razini.

Budući da je doktorsko obrazovanje utemeljeno u promišljanju o znanstvenoistraživačkom identitetu znanstvenog polja, u radu su se propitale teorijske dvojbe koje su oblikovale konceptualna polazišta današnjega reformiranog Doktorskog studija informacijskih i komunikacijskih znanosti u Zagrebu. U radu je propitana i raspravljena intelektualna i teorijska disperzija u informacijskim znanostima koja se u procesu restrukturiranja programa iskazala kroz potrebu prevladavanja tradicionalnih polarizacija koje su obilježavale polje (korisnici nasuprot tehnologije, kvalitativna nasuprot kvantitativne metodologije, usmjerenost na institucije nasuprot usmjerenosti na informacijske procese i prakse i sl.).

U novom se reformiranom programu informacijskih i komunikacijskih znanosti opisane distinkcije premošćuju modularnim pristupom koji omogućuje odmak od fiksirane sadržajne jezgre te omogućuju izloženost studenata različitim širokim perspektivama i gledištima. Takav pristup osigurava komplementarnost $\mathrm{s}$ EU-smjernicama o doktorskom obrazovanju koje ističu individualizirani pristup, a modularni model omogućuje studentima aktivno sukreiranje programa i definiranje hoda kroz studij prema vlastitom istraživačkom interesu. Svrha je ovog rada bila potaknuti daljnje rasprave o doktorskim studijima u području informacijskih (i komunikacijskih) znanosti koji su na globalnoj razini, kao što je konstatirano u radu, rijetko obrađivani te doprinijeti uvidima u njihovu evoluciju, konceptualnu strukturu i održivost u dinamičnom polju kao što su informacijske i komunikacijske znanosti. 


\section{LITERATURA}

Bawden, D. Smoother pebbles and the shoulders of giants: the developing foundations of information science. // Journal of Information Science 34, 4(2008), 415-426. DOI: http://dx.doi.org/10.1177/0165551508089717

Bologna Seminar on "Doctoral Programmes for the European Knowledge Society", (Salzburg, 3-5 February, 2005). Conclusions and recommendations. [citirano: 201811-10].

Dostupno na: https://eua.eu/downloads/publications/salzburg\%20recommendations\%202005.pdf

Borgman, C. L.; R. E. Rice. The convergence of information science and communication: a bibliometric analysis. // Journal of the American Society for Information Science 43, 6(1992), 397-411. DOI: https://doi.org/10.1002/(SICI)1097-4571(199207)43:6<397::AID-ASI1 >3.0.CO;2-M

Druin, A.; P. T. Jaeger; J. Golbeck; K. R. Fleischmann; J. Lin; Y. Qu; P. Wang; B. Xie. The Maryland modular method: an approach to doctoral education in information studies. // Journal of Education for Library and Information Science 50, 4(2009), 293-301. Dostupno i na: https://www.jstor.org/stable/40732590?seq=1\#metadata_ info_tab_contents [citirano: 2018-11-10].

Ferlindeš, J.; S. Špiranec. Teorijsko-filozofsko utemeljenje knjižnične i informacijske znanosti u filozofiji informacije. // Vjesnik bibliotekara Hrvatske 61, 1(2018), 37-56. DOI: https://doi.org/10.30754/vbh.61.1.572

Kent State University. Ph.D. in Information and Communication. [citirano: 2018- 1110]. Dostupno na: https://www.kent.edu/iSchool/phd-communication-information-2

Kottmann, A.; E. Weyer. Exploration of the implementation of the principles for innovative doctoral training in Europe: final report. Brussels: European Commission, 2013. [citirano: 2018- 11-10]. Dostupno na: http://doc.utwente.nl/88802/

Larivière, V.; C. R. Sugimoto; B. Cronin. A bibliometric chronicling of library and information science's first hundred years. // Journal of the American Society for Information Science and Technology 63, 5(2012), 997-1016. DOI: https://doi.org/10.1002/ asi. 22645

Ostvarivanje Europskog prostora visokog obrazovanja: priopćenje sa Konferencije ministara visokog obrazovanja, Berlin, 19. rujna 2003. [citirano:2018- 11-10]. Dostupno na: https://www.idi.hr/cerd/uploads/DOKUMENTI/Bolonja/Berlinska_deklaracija.pdf

Pravilnik o znanstvenim i umjetničkim područjima, poljima i granama. // Narodne novine 118(2009), 82(2012), 32(2013), 34(2016). Dostupno i na: http://www.propisi.hr/ print.php?id=9662 [citirano: 2018- 11-10]. 


\section{J. Lasić-Lazić, S. Špiranec:DOKTORSKI STUDIJ INFORMACIJSKIH I ...}

Robinson, L.; M. Karamuftuoglu. The nature of information science: changing models. // Information Research: An International Electronic Journal 15,4(2010). [citirano: 2018- 11-10]. Dostupno na: http://www.informationr.net/ir/15-4/colis717.html

Rutgers., Ph.D. in Communication, Information \& Media. [citirano: 2018- 11-10]. Dostupno na: https:/comminfo.rutgers.edu/academics/graduate/phd-program-communication-information-and-media

Salzburg II preporuke: postignuća europskih sveučilišta u razdoblju nakon 2005. u ostvarivanju Salzburških načela. Zagreb: Sveučilište u Zagrebu, 2011. [citirano: 2018- 11-10]. Dostupno na: http://www.unizg.hr/fileadmin/rektorat/Istrazivanja/ Poslijediplomski/Ured_za_doktorske_studije_i_programe/Publikacije/Salzburg_II_ preporuke.pdf

Strategija doktorskog studija Informacijske i komunikacijske znanosti: 2015. - 2020. // Sveučilište u Zagrebu. Filozofski fakultet. Odsjek za informacijske i komunikacijske znanosti. [citirano: 2018- 11-10]. Dostupno na: https://inf.ffzg.unizg.hr/index. $\mathrm{php} / \mathrm{hr} / \mathrm{studij} /$ poslijediplomski-doktorski-studij/plan-i-program

Sugimoto, C. R.; T. G. Russell; S. Grant. Library and information science doctoral education: the landscape from 1930-2007. // Journal of Education for Library and Information Science 50, 3(2009), 190-202. Dostupno i na: https://www.jstor.org/stable/40732578 [citirano: 2018- 11-10].

Težak, B. Informaciono-dokumentaciono-komunikacioni (INDOK) sistem. // Informatologia Yugoslavica 1, 1/4(1969), 1-2.

Težak, B. Referalni centar Sveučilišta u Zagrebu: (pregledni, bitni i osobiti podaci o Referalnom centru). // Informatologia 40, 1(2007), 14-19. Dostupno i na: https://hrcak. srce.hr/index.php?show=clanak\&id_clanak_jezik=20458 [citirano: 2020-08-20].

UCD School of Information and Communication Studies Doctoral Programme. [citirano: 2018- 11-10]. Dostupno na: https://www.ucd.ie/ics/study/phdresearchprogrammes/

Zins, C. Conceptions of information sciences. // Journal of the American Society for Information Science and Technology 58, 3(2007), 335-350. DOI: https://doi. org/10.1002/asi.20507

Zins, C. Conceptual approaches to defining data, information, and knowledge. // Journal of the American Society for Information Science and Technology 58, 4(2007), 479493. DOI: https://doi.org/10.1002/asi.20508

Zins, C. Knowledge map of information science. // Journal of the American Society for Information Science and Technology 58, 4(2007), 526-535. DOI: https://doi. org/10.1002/asi.20505

Zins, C. Classification schemes of information science: twenty-eight scholars map the field. // Journal of the American Society for Information Science and Technology 58, 5(2007), 645-672. DOI: https://doi.org/10.1002/asi.20506 